\title{
Clinical Profile of Patients with Varicose Vein Attending Tertiary Care Hospital
}

\author{
Sapna Purushotham ${ }^{1}$, Ravikar Jayaraj ${ }^{1}$ \\ ${ }^{1}$ Associate Professor, Department of Surgery, East Point College of Medical Sciences, Bangalore, Karnataka.
}

\section{Abstract}

Background: The exact etiology of Varicose Veins is not clearly known. The fact that the human race gets Varicose Veins at all is probably due to our evolutionary adoption of the erect posture. The superficial veins of the legs being between three and four feet below the heart, and unsupported except by connective tissue are in poor position to withstand continuous venous hypertension and so they become enlarged and tortous i.e., varicose. Subjects and Methods: Patient who satisfy inclusion and exclusion criteria are subjected to clinical examination, Duplex ultrasound and Basic pre-operative investigations for surgery. History and examinations were completed as mentioned in the proforma. The patient was examined in standing position with good illumination, exposing both the lower limbs completely. Results: Study subjects included both males and females, Males comprised of 45\% whereas females 55\%.Majority of patients were unskilled workers (68.3\%).Housewives formed $16.7 \%$. Conclusion: The most common complaint was pain, pigmentation and eczema.

Keywords: Varicose Vein, Pigmentation and Eczema.

Corresponding Author: Dr. Ravikar Jayaraj, Associate Professor, Department of Surgery, East Point College of Medical Sciences, Bangalore, Karnataka.

Received: December 2019

Accepted: December 2019

\section{Introduction}

The Long Saphenous Veinis the extension of medial venous arch in front and lateral to the medial malleolus running up anteromedial surface of tibia and posteromedial to knee joint ascending to the foramen ovule and piercing cribriform fascia 3 to $3.5 \mathrm{cms}$ below and lateral topubic tubercle terminating into the femoral vein. Except in the middle third where it is subcuticular it is resting over the deep fascia. ${ }^{[1]}$ Saphenous nerve is in close relation to the vein in the distal $2 / 3 \mathrm{rd}$ of the leg where it is likely to be injured. Lymphatic are its close accompaniments throughout the dorsum and the anteromedial surface of the whole limb terminating into superficial group of Lymph nodes. Apart from its connection with dorsal arch there are communicating veins between short and long Saphenous Vein in the distal 1/3 of leg. ${ }^{[2]}$

The valves of the leg veins are profuse and of great importance in the pump machines, whereby in the upright position, blood is returned to the heart against gravity. In the venous sinuses of the soleus muscle there are no valves, but in all the muscular veins draining both the soleus and gastrocnemius muscles, valves are numerous. The posterior tibial and peroneal veins and anterior tibial veins are closely valved, the valves being situated every inch or so. ${ }^{[3]}$

In addition all the perforating vein in the lower part of the calf and all veins connecting the deep with the superficial veins in all parts of the lower limb are valved so that normally blood can only pass from the superficial to the deep veins and reflux backwards is prevented.

The arrangement of valves in the large deep venous trunks, the popliteal, femoral, common femoral and iliac veins, is variable, but knowledge of this is important in considering the aetiology of both superficial varicose veins, and deep venous incompetence.

Cockett and Dodd, studied a series of cases, dissecting venous system of the lower limbs from inguinal ligament or popliteal fossas, for the purpose of mapping out valves.

The valves of the long and short saphenous vein are important in the prevention of reflux and of varicose dilatation of the tributaries of these trunks. A study of the lumina of varicose saphenous veins removed at operation has shown there this valves can be divided into two types -Major and ordinary. ${ }^{[4]}$

Major valves consist of strong white cusps with firm thickened, attachments to the vein wall with obvious sinuses above and are usually at the end of the venoustrunks. They are occasionally seen, one in the middle of the long saphenous vein below the point of entry of the posterior arch and anterior veins of the leg i.e, at the level of knee.

Ordinary valves are delicate structures. Their cusps are almost transparent. There is a little or no change in the view all either in consistency or size of lumen where they are attached. They are not easily seen, but when a trickle of water is run in them centrifugally, the cusps float outwards 
and they become visible. There are one or occasionally two major valves in the terminal $2-3 \mathrm{cms}$. And there after 10 to 20 ordinary valves upto the ankle. Gray's Anatomy (1954) remarks that there are more in the leg than in the thigh. ${ }^{[5]}$

The short saphenous vein is rather more than half the length of the long saphenous vein, but it is more closely valved. It has a major valve at its termination and has 6-12 ordinary valves in its trunk to ankle. The more peripheral the vessel is the more frequently it is valved. Major valves consist of strong white cusps with firm thickened, attachments to the vein wall with obvious sinuses above and are usually at the end of the venous trunks. They are occasionally seen, one in the middle of the long saphenous vein below the point of entry of the posterior arch and anterior veins of the leg i.e, at the level of knee. Ordinary valves are delicate structures. Their cusps are almost transparent. There is a little or no change in the view all either in consistency or size of lumen where they are attached. They are not easily seen, butwhen a trickle of water is run in them centrifugally, the cusps float outwards and they become visible.

There are one or occasionally two major valves in the terminal $2-3 \mathrm{cms}$. And there after 10 to 20 ordinary valves up to the ankle. Gray's Anatomy (1954) remarks that there are more in the leg than in the thigh.

The exact etiology of Varicose Veins is not clearly known. The fact that the human race gets Varicose Veins at all is probably due to our evolutionary adoption of the erect posture. The superficial veins of the legs being between three and four feet below the heart, and unsupported except by connective tissue are in poor position towithstand continuous venous hypertension and so they become enlarged and tortous i.e., varicose. ${ }^{[6]}$

Factors such as Heredity, Race, Obesity, Intercurrent disease, chest disease, age and even constipation have all been the subject of prolonged investigations and discussion.

\section{Subjects and Methods}

Each patient with a typical history of symptomatic varicosiswas subjected to physical examination and preliminary investigations.

\section{Inclusion Criteria}

- Symptomatic varicosis of GSV

- Insufficiency of SFJ as determined by duplex ultrasound scanning.

- $\quad$ Age $>18$ years

- $\quad$ Signed informed consent

- $\mathrm{C}_{>2}, \mathrm{E}_{\mathrm{p}}, \mathrm{A}_{\mathrm{s}}, \mathrm{P}_{\mathrm{r}}$ (Clinical, Etiological, Anatomical, Pathological)

- Ipsilateral Recurrent varicose veins after stripping

- SSV insufficiency

- Previous GSV thrombophlebitis

- Malignancy, renal insufficiency, Uncontrolled Diabetes mellitus, immunosuppressive medication

- Deep vein thrombosis.

Patient who satisfy inclusion and exclusion criteria are subjected to clinical examination, Duplex ultrasound and Basic pre-operative investigations for surgery.
History and examinations were completed as mentioned in the proforma. The patient was examined in standing position with good illumination, exposing both the lower limbs completely.

Result

Table 1: Age Distribution of Patients Studied

\begin{tabular}{|l|l|l|}
\hline Age group & Frequency & Percentage \\
\hline $26-30$ years & 7 & 11.67 \\
\hline $31-40$ years & 28 & 46.67 \\
\hline $41-50$ years & 23 & 38.33 \\
\hline More than 50 years & 2 & 3.33 \\
\hline Total & 60 & 100 \\
\hline
\end{tabular}

Maximum number of patients were in the age group of $31-$ 40 years $(46.67 \%)$ followed by $41-50$ years $(38.33 \%)$.

Table 2: Gender Distribution of Patients Studied

\begin{tabular}{|l|l|l|}
\hline Gender & Frequency & Percentage \\
\hline Male & 27 & 45 \\
\hline Female & 33 & 55 \\
\hline Total & 60 & 100 \\
\hline
\end{tabular}

Study subjects included both males and females, Males comprised of $45 \%$ whereas females $55 \%$.

Table 3: Comparison of Occupation in Two Groups of Patients Studied

\begin{tabular}{|l|l|l|}
\hline Occupation & Frequency & Percentage \\
\hline Unskilled & 41 & 68.3 \\
\hline Service & 9 & 15 \\
\hline Housewife & 10 & 16.7 \\
\hline Total & 60 & 100 \\
\hline
\end{tabular}

Majority of patients were unskilled workers (68.3)

Housewives formed $16.7 \%$.

Table 4: Comparison of Chief Complaints in Two Groups of Patients Studied

\begin{tabular}{|l|l|}
\hline Chief complaints & Frequency \\
\hline Eczema, edema & 1 \\
\hline Eczema, pain,Pigmentation & 9 \\
\hline Eczema, pigmentation & 2 \\
\hline Eczema, ulcer & 1 \\
\hline Pain, Eczema & 11 \\
\hline Pain, Eczema, edema & 3 \\
\hline Pain, edema & 2 \\
\hline Pain, pigmentation & 12 \\
\hline Pain, ulcer & 6 \\
\hline Pigmentation, pruritis & 6 \\
\hline Ulcer & 2 \\
\hline Ulcer, pain, eczema & 3 \\
\hline Ulcer, pigmentation & 3 \\
\hline
\end{tabular}

The most common complaint was pain, pigmentation and eczema.

Table 5: Comparison of Limb in Two Groups of Patients Studied

\begin{tabular}{|l|l|l|}
\hline Limb & Frequency & Percentage \\
\hline Left & 25 & 41.6 \\
\hline Right & 35 & 58.4 \\
\hline Total & 60 & 100 \\
\hline
\end{tabular}




\section{Discussion}

Gay's (1812-1885) work appears to be the first scientific investigation of theseconditions. He pointed out that there may be other serious lesions affecting both arteries and veins, deep and superficial and believed that venous thrombosis played an important role. ${ }^{[7]}$

Harvey and Lower gave the concept of leg muscle pump theory. ${ }^{[8]}$

Sir Benjamin Brodie (1783-1862) was first to demonstrate reflux in the saphenousvein and advocated conservative treatment for all but the most severe cases. He developed a system of double bandaging and recommended elevation of the limb. ${ }^{[9]}$

Friedrich Trendelenburgh (1841-1924) and his disciple George Perthes, advocatedligation of saphenous vein and were successful in treating the varicose ulcers. ${ }^{[10]}$

In 1930, Linton emphasized the pathological contribution of incompetent perforating veins to venous insufficiency.

The introduction of stripper has been attributed to William Keller in 1905, CharlesMayo in 1906 and Stephen Babcock in 1907. ${ }^{[1]}$

The kellers instrument was a flexible intraluminal wire that turned the vein inside out, May instrument was an external ring that was passed along the vein, cutting the tributaries as it went, Babcock used an intraluminal stripper with an acron shaped head that pleated the vein along its length, as do strippers in use today. The Keller operation was given up because it was ill conceived, the Mayo, because of severe hemorrhage and Babcock probably because the instrument was too short, too straight and flexible.

In 1908 BeniaminoSchiassi in Bologna, first used iodine as sclerosant.

1980s saw the emergence of duplex and Doppler which revolutionized the management of vascular disease. ${ }^{[12]}$

Numerous comparative studies were conducted. Recent trends like SEPS (Subfascial endoscopic perforator surgery), Endovenous laser ablations, Endovenous radio frequency ablation, Endovenous LSV stripping have revolutionized the patient care.

\section{Conclusion}

- Maximum number of patients were in the age group of $31-40$ years $(46.67 \%)$ followed by $41-50$ years $(38.33 \%)$

- The most common complaint was pain, pigmentation and eczema.

\section{References}

1. Michael J.Callam. "Varicose Veins" in Essential surgical practice, Module 34, 4th edition, 2002 Hodder Arnold Publications.879-890.

2. Andrew Bradbury, Christine Evans, Paul Allan, Amanda Lee, C Vaughan Ruckley, F G R Fowke What are the symptoms of varicose veins Edinburgh vein study crosssectional population survey.BMJ 1999; 318:353-35.

3. Johnson G,Jr. 'Management of Venous Disorders'. In Vascular surgery by Rutherford RB, 4thEdn. Vol II, W.B. Sounders company;1995: 1671-1862.

4. Dodd H.J, Cockett F.B. The Pathology and Surgery of the veins of the lower limb. 2nd Edn, Churchill Livingstone; 1976.

5. Williams PJ, Bannister LH. Berry MM et al., "Veins of Lower Limb" in Grey's Anatomy, Churchill Livingstone publications Ch10, 38thEdn: 1995: 1595-1598.

6. Carlos L, Junquier, Carneiro J, "The Circulatory System" in Basic Histology - Text and atlas, Lange Publications,Ch.11, 10thEdn: 225230.

7. Lacroix H, Nevelsteen A, Suy R (1999) Invaginating versus classic stripping of the long saphenous vein. A randomized prospective study. ActaChirBelg 99(1):22-25.

8. Durkin MT, Turton EP, Scott DJ, et al. (1999) A prospective randomised trial of PIN versus conventional stripping in varicose vein surgery. Ann R CollSurgEngl 81(3):171-174.

9. Eklof B, Rutherford RB, Bergan JJ, et al. (2004) American Venous Forum International Ad Hoc Committee for Revision of the CEAP Classification. Revision of the CEAP classification for chronic venous disorders: consensus statement. J VascSurg 40(6):1248-1252

10. Fullarton GM, Calvert MH (1987) Intraluminal long saphenous vein stripping: A technique minimizing perivenous tissue trauma. $\mathrm{Br} \mathrm{J}$ Surg 74:255.

11. Goren G, Yellin AE (1995) Minimally invasive surgery for primary varicose veins: Limited invaginal axial stripping and tributary (hook) stab avulsion. Ann VascSurg 9(4):401-414.

12. Bearn P, Fox JA (1993) A modified technique for stripping of the long saphenous vein. Phlebology 8:32-33.

Copyright: (C) the author(s), 2019. It is an open-access article distributed under the terms of the Creative Commons Attribution License (CC BY 4.0), which permits authors to retain ownership of the copyright for their content, and allow anyone to download, reuse, reprint, modify, distribute and/or copy the content as long as the original authors and source are cited.

How to cite this article: Purushotham S, Jayaraj R. Clinical Profile of Patients with Varicose Vein Attending Tertiary Care Hospital. Acad. J Surg. 2019;2(2):52-54.

DOI: dx.doi.org/10.21276/ajs.2019.2.2.14

Source of Support: Nil, Conflict of Interest: None declared. 